\title{
40
}

\section{REMEDIATION OF CONTAMINATED SOILS}

\section{Experience from two sites in Sweden}

\author{
Lars Bevmo \\ Peter Englöv \\ VBB Viak, Malmö \\ Sweden
}

\begin{abstract}
Experience from remediation of two old abandoned industrial sites is reviewed. One case is a tannery site where sludge lagoons and a solid waste dump have been covered by clay and turned into a park area. The other case is a wood preservation plant where arsenic polluted soil has been cleaned by washing before the site will be open to public for sport activities and recreation. The main contaminants, the reasons for chosen remediation measures and experience from the remediation works are presented.
\end{abstract}

\section{BACKGROUND}

Remediation of old olluted industrial sites have been discussed during long time in Sweden. Investigations have been performed at many sites but only a few have been remediated mainly due to lack of money for neccessary measures.

During 1995 the Swedish Government allocated 75 MSEK (million swedish crowns) for remediation of old sites. The most costly project was an old tannery site, Glace, in the city centre of Kävlinge to wich project 14.3 MSEK was granted. VBB Viak, which proposed the city to apply for grants based upon earlier performed investigations, was appointed by the city to assist with project management and all consulting work needed for the project. All construction and earth works have been performed by a local contractor, Eslövs Grävmaskiner AB.

During a period of 35 years Televerket (the Swedish telephone company) ran a plant for preservation of wooden poles in Hjältevad about $80 \mathrm{~km}$ east of Jönköping, in the southern part of Sweden. Since 1983 different types of investi- 
gations have been conducted to clarify the environmental conditions and to evaluate alternative remedial technologies. In 1996 a final decision was taken to remediate the site. Soil washing was chosen as the principal treatment technology. The project, which is the first real soil washing project in Sweden, is realized in 1997.

The project is financed by Telaris, which is a subsidiary to the Swedish Telecom and responsible for the properties within the company group.

Soil washing contractor is the Swedish-Dutch company Gotthard Heidemij Marksanering $\mathrm{AB}$. Construction works are made by Bjursells, a Skanska subsidiary. The rest fraction from the soil washing and highly contaminated not processed soil are handled and contained by SAKAB. Consultant is VBB Viak.

\section{GLACÉ TANNERY, KÄVLINGE}

\section{Polluted areas}

The industrial site is situated on a river bank in the city center of Kävlinge in the southern part av Sweden. The tannary production started 100 years ago but ended 1989 due to economic reasons. Different production methods have been used during the years as well as many different chemicals.

The site consist of four parts that is

- the industrial buildings incl. paved areas, 1,5 ha

- the sludge lagoon areas, 3 ha

- the solid waste dump, 1,5 ha

- non-polluted traffic and green areas, 1 ha.

Originally the waste water from the tannery was discharged directly to the river. During the 50-ies sedimentation and later on chemical treatment was introduced resulting in some $50.000 \mathrm{mt}^{3}$ of sludge polluted by chromium, arsenic and DDT.

The industry has had its own waste dump within the site. The dump contains some $30.000 \mathrm{mt}^{3}$ of solid waste of different kinds from the industry including leather trimmings, ashes, construction waste, empty chemical barrels etc.

Part of the ground close to the factory has also been polluted by chlorinated solvents caused by leakage from a concrete tank.

\section{Reamediation measures}

Based upon long series of environmental investigations - soil, groundwater and river water analyses - it was found the only feasible remediation measure to be covering of the polluted areas by clay and earth in order to prevent direct contact between polluted soil and human beings and animals. Further the clay cover will minimize the infiltration of rainwater and leakage of contaminated groundwater. In that way the emissions to the river will be kept at an acceptable level. Altemative measures, such as removal or treatment of polluted soil was investigated but 
found too costly and time consuming as well as implying a risk not to be successful at all.

The pollution of chlorinated solvents has been thouroughly investigated, analyzed and assesed. It was found that a natural degradation takes place in the ground and that the pollution does not imply any great hazard to the river. Thus no special measures were deemed to be neccessary at this stage, however the degradation process will be included in a monitoring programme.

\section{Experience}

According to the conditions for the grant all measures should be finalized during 1996. Neccessary permits from the environmental authorities had to be applied for as well as demolishing of parts of the industrial buildings. Another important issue was to decide how to manage and contract the neccessary works.

Early a steering comittee with representatives from all involved parties was appointed. The main task for the committee was to set out policies and advise the work within the frame of the budget. Management of the works was given to a small working group with representatives of the owner of the site, the municipality and the consulting engineer. Only the demolishing of the main building was contracted on a turnkey lump sum basis while all other works were managed by the working group with machines and personnel contracted on a daily fee basis.

During the cause of the works an important issue was to find neccessary cover and earth material. By negotiations it was possible to cooperate with outside contractors to get excess excavated material from their sites. Mostly the agreements made implied that a lot of extra material was transported to the site. Thus the final cover was some $3 \mathrm{~m}$ of clay in two layers with an intermediate layer of concrete rubble and bricks in between as protection for uncautious digging. The thickness of the cover has therefore been more the double the originally intended one, however, still within the budget.

Most of the material from the demolishing of the buildings has been reutilized and only some $2 \%$ has been put into a landfill. During the cause of the works 19 manyears of work was created most of them being unemployed labour appointed by the authorities. Due to tight management the works were performed within the time and the budget limits with a substantially increases quality from environmental point of view. Further the work has resulted in a new recreational park close to the river in the central part of Kävlinge being highly appreciated and enjoyed by all inhabitants.

The main reasons for the good result of the project are the way of contracting the works, an experienced and good contractor, efficient cooperation with other construction projects as well as interested and cooperative environmental authorities. 


\section{THE HJÄLTEVAD PROJECT}

\section{Contaminants and polluted area}

The wood preservation plant in Hjältevad was erected in 1949 and the main process was pressure impregnation with water soluble salts containing arsenic, copper and chromium.

The plant is situated on a glaciofluvial deposit with gravelly sand in a top bed (3$4 \mathrm{~m}$ ). Under the groundwater table ( $3 \mathrm{~m}$ below ground) the texture of the soil is successively finer. Silt dominates at a depth of $12-15 \mathrm{~m}$.

The preservation of poles was conducted in a $26 \mathrm{~m}$ long cylinder with a diameter of $1.5 \mathrm{~m}$. This was situated in the centre of the approximately 50000 mê large area $(130 \mathrm{~m} \times 400 \mathrm{~m})$. Beside the impregnation equipment there were also other types of big machinery tools like saws and a turning lathe. The main part of the area also comprised storage areas for treated as well as not treated poles.

About 1000000 poles were treated on the plant until it was closed down in 1985.

The contaminants, e.g. arsenic, copper and chromium, have been spread to the environment in two different ways. The superficial soil layers have been contaminated through spill in connection with chemicals handling and leakage from treated poles. The other way of emission is leakage from an under ground storage tank of impregnation liquid. The tank leakage was dicovered in 1968 and the tank made of steel was replaced by a new concrete tank. The discharge into the groundwater is not known, but it is estimated to be several tens of me

The investigations have shown that arsenic is the main contaminent analyzed in the highest concentrations. The mobility is very low for all three contaminants, however, arsenic is found to be somewhat more mobile than both copper and chromium. Because of that reason and since arsenic is considered to be the most toxic of the three compounds, the arsenic content has been governing in risk assessments and as basis for remedial measures.

At the soil surface and within storage areas for treated poles typical arsenic concentrations are $100-1000 \mathrm{mg} / \mathrm{kg}$ DS (Dry Solids). At a depth of $20-25 \mathrm{~cm}$ the concentrations in general have fallen to one tenth of the concentration just at the surface. In the vicinity of the impregnation cylinder the concentrations are much higher; $10000 \mathrm{mg} / \mathrm{kg}$ DS and more is not unusual. The penetration is also deeper; 1-2 m below ground level.

Downstreams the storage tank the soil and groundwater is contaminated to a depth of about $7 \mathrm{~m}$ below groundwater table. The arsenic concentrations are highest close to the tank; $100-1000 \mathrm{mg} / \mathrm{kg}$ DS. At a distance of $50 \mathrm{~m}$ the mean concentration in groundwater bearing strata is $40-50 \mathrm{mg} / \mathrm{kg}$ DS. 
The total amount of arsenic in the soil has been calculated to 6-7 tonnes. An essential part of this is found at low concentrations $(<30 \mathrm{mg} / \mathrm{kg})$.

\section{Remedial alternatives}

Different types of remedial measures have been considered. However, it was assessed some sort of containment to be necessary part in all solutions, because reuse of the compounds (especially arsenic) is not realistic. The main question has been where to find an acceptable site for disposal or other type of containment; Is containment on site acceptable or should an external deposit be used? Is it favourable to concentrate the contaminants before containment? The latter question is relevant primarily at the ex situ-case.

After inventory no existing disposal site was found to be able to receive the actual amounts of contaminated soil (25-50 000 tonnes). A feasibility study showed, however, that an on-site containment solution was a realistic alternative. Most of the contaminated soils under the groundwater table could be contained within a 12-15 m high vertical barrier upon which contaminated superficial soils were proposed to be collected and placed covered by a horizontal barrier.

As an alternative to ex-situ disposal of untreated soil, also different types of preconcentration was evaluated, e.g. a geokinetical method and soil washing. The conclusion of the studies was that soil washing could be a realistic complement to disposal (of a restfraction of 10-20\%). This smaller, but higher concentrated, restfraction could be received by SAKAB.

The final proposal, approved by the authorities, also comprises on-site washing of about 25000 tonnes of soil with an arsenic concentration higher than 40 $\mathrm{mg} / \mathrm{kg}$ DS. The restfraction, which is estimated to 5000 tonnes, will be recieved by SAKAB. Treated soil will be left on the site. Soil with arsenic concentration in the span $15-40 \mathrm{mg} / \mathrm{kg}$ DS. will be collected and placed in a concentrated area within the site and covered by $1 \mathrm{~m}$ soil with a arsenic concentration of less than $15 \mathrm{mg} / \mathrm{kg}$ DS.

It is estimated that about 4 tonnes of arsenic will be removed from the site mainly in the restfraction, but also in highly contaminated, not treated soil.

When the remedial measures have been completed the site will be planned and used for sport activities and recreation.

\section{Experience}

The soil washing is nearly completed (September 1, 1997). As planned nearly 25000 tonnes soil will be treated. The restfraction will be about 2500 tonnes, which is far less than calculated. As calculated about 4 tonnes of arsenic will be removed from the site. The result of the washing of superficial soil is as good as expected. The soil from the below groundwater formation has been much more difficult to treat than presumed (the contaminants have deeply penetrated the soil particles). 
The time schedule is kept and the remedial measures will be finished during 1997. Also the overall project budget (30-40 MSEK) will be kept.

The interest for the project has been overwhelming and some hundred visitors from industries, real estate companies, contractors, consultants and authorities have visited the site during this summer.

\section{REFERENCES}

\section{(All in Swedish)}

1. VBB 1989, Feasibility Study of rehabilitation works för Tannery in Kävlinge,

2. VBB 1990, Additional investigations and Final Report on remedial works for Tannery in Kävlinge

3. VBB Viak 1995, Environmental investigations at Glacé Tannery

4. VBB Viak, Anox 1997, Investigation of chlorinated solvents in groundwater at Glacé Tannery, Kävlinge

5. VBB Viak 1997, Final Report Environmental Control of remediation works at Glace Tannery Kävlinge 